\title{
Pengelolaan Air Bersih Dengan Metode Fisika Dan Kimia Pada SMA Luqman Al-Hakim
}

\author{
Tubagus Noor Rohmannudin, Lukman Noerochim, Budi Agung Kurniawan, Hariyati \\ Purwaningsih, Zaid Sulaiman, Sulistijono \\ Institute Teknologi Sepuluh Nopember, Surabaya \\ Email: roma_r2001@yahoo.com \\ DOI: $10.18196 / p p m .36 .320$
}

\begin{abstract}
Abstrak
Kondisi air yang keruh di kawasan Surabaya utara mengakibatkan masyarakatnya tidak bisa menggunakan air tersebut untuk keperluan seharihari. Kondisi ini disebabkan karena Surabaya utara merupakan kawasan dekat pantai, adanya pencemaran dari limbah industri dan limbah rumah tangga. Sehingga diperlukan teknologi pengolahan air bersih untuk mengolah air tanah menjadi air bersih. Metode pelatihan yang digunakan adalah presentasi materi dan demostrasi pengolahan air bersih. Untuk mengetahui kompetensi peserta pelatihan dilakukan ujian pretest dan postest. Hasil pelatihan ini menunjukan adanya peningkatan kompetensi, wawasan dan pemahaman Guru dan Siswa SMA Luqman Al-Hakim mengenai proses pengolahan air bersih, hal ini dibuktikan dengan peningkatan nilai dari ujian Pretest dan Postest.
\end{abstract}

Kata Kunci: Pelatihan, Pengolahan Air Bersih, Fisika, Kimia

\section{Pendahuluan}

Surabaya utara yang meliputi dari Kecamatan Bulak, Kenjeran, Semampir, Pabean Cantilan, Krembangan mengalami pencemaran air yang cukup tinggi. Konsentrasi zat organik di kali Surabaya relatif tinggi terutama pada saat musim kemarau (Yudo \& Said, 2019). Hal ini dibuktikan dengan konsetrasi BOD tertinggi mencapai 14,84 mg/l dan COD tertinggi mencapai $53,87 \mathrm{mg} / \mathrm{l}$. Nilai tersebut merupakan nilai yang sangat tinggi jika dibandingkan dengan Standar Mutu Air kelas I sesuai dengan PP Nomor 82 tahun 2001 yaitu nilai untuk BOD dan COD adalah $2 \mathrm{mg} / \mathrm{l}$ dan $10 \mathrm{mg} / \mathrm{l}$.

Kandungan bahan-bahan yang berbahaya atau beracun pada air yang tercemar kadang bisa dilihat dari penampilan fisik air. Air yang berwarna kuning kecoklatan atau coklat kemungkinan banyak mengandung mangan dan besi. Apabila dikonsumsi secara terus-menerus dalam waktu yang lama akan merusak ginjal dan usus (Febriana \& Ayuna, 2015). Selain itu, bau busuk yang sering tercium dari air menandakan adanya pelapukan bahan-bahan organik oleh mikroorganisme yang seperti kuman dan bakteri di air. Kuman dan bakteri dapat membahayakan bagi kesehatan. Oleh sebab itu diperlukan proses khusus untuk menghilangkan kuman dan bakteri pada air yang akan diminum.

Berdasarkan hal tersebut, Departemen Teknik Material dan Metalurgi FTIRS-ITS tergerak untuk mengadakan program pengabdian kepada masyarakat dengan membuat sebuah pelatihan mengenai teknologi pengolahan air bersih. Pelatihan tersebut bersifat sebagai transfer ilmu dan teknologi sehingga lebih tepat dilaksanakan untuk kalangan SMA/ SMK/ Sederajat sebagai peningkatan kompetensi Guru dan Siswa. Salah satu SMA tersebut adalah SMA Luqman Al-Hakim Surabaya. Hal ini dibuktikan dengan antusiasnya para guru dan Siswa SMA Luqman Al-Hakim Surabaya untuk mengikuti program ini ketika diadakan promosi oleh tim pengabdian dari Departemen Teknik Material dan Metalurgi FTIRS-ITS. Melalui pelatihan ini diharapkan dapat membantu peningkatan mutu pendidikan khususnya ilmu dan teknologi pengolahan air bersih untuk para Guru dan Siswa SMA Luqman Al-Hakim Surabaya.

Tujuan program pengabdian masyarakat kali ini adalah memberikan ilmu pengetahuan konsep dasar teknologi pengolahan air bersih untuk meningkatkan pemahaman dan kompetensi guru dan siswa SMA Luqman Al-Hakim Surabaya. Serta mendiskusikan aplikasi penggunaan 
teknologi pengolahan air bersih yang sederhana sehingga dapat diaplikasikan oleh guru dan siswa.

\section{Metode Pelaksanaan}

Strategi program pengabdian masyarakat kali ini adalah tim melakukan studi lapangan dan mengumpulkan informasi. Kemudian tim memberikan penyuluhan tentang pelatihan teknologi pengolahan air bersih dan menginformasikan kegiatan pelatihan. Lalu tim memfasilitasi program pelatihan yang diadakan secara virtual via aplikasi Zoom dan melakukan monitoring dan evaluasi program pelatihan. Selanjutnya tim membuat perencanaan program berkelanjutan.

Pelatihan kali ini dilakukan selama 2 hari. Gambar 1 merupakan kegiatan hari pertama adalah penyampaian materi oleh tim pengabdi. Materinya yang diberikan adalah sebagai berikut

1. Pencemeran lingkungan

2. Pengolahan air bersih

3. Aplikasi pengolahan air bersih dengan metode penyaringan

4. Contoh praktikum mengetahui indikator air tercemar

Gambar 2 menunjukkan kegiatan hari kedua yaitu presentasi dari para siswa terkait sumur resapan dan pengolahan air gambut, kemudian dilanjutkan diskusi terkait pengolahan air bersih serta contoh aplikasi penyaringan air bersih yang berada di Indonesia.

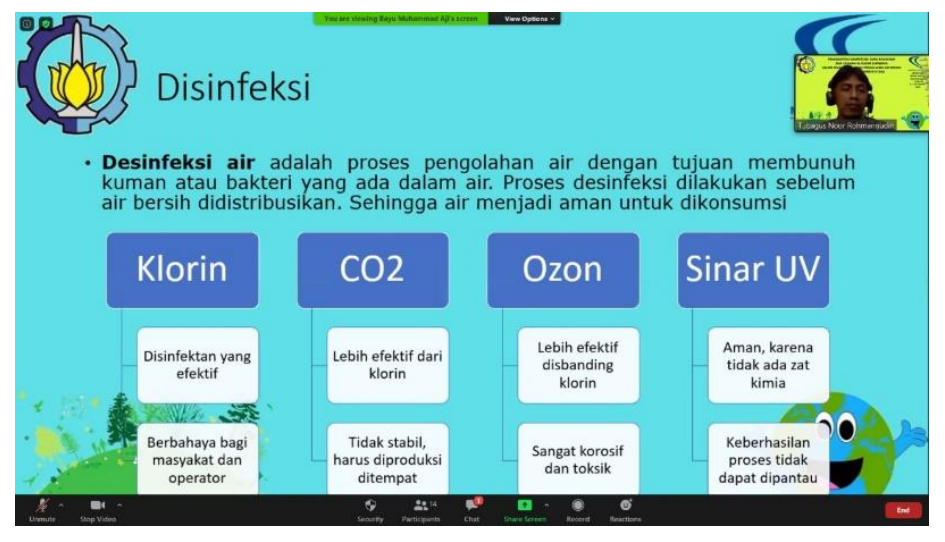

Gambar 1 Penyampaian materi oleh tim pengabdi

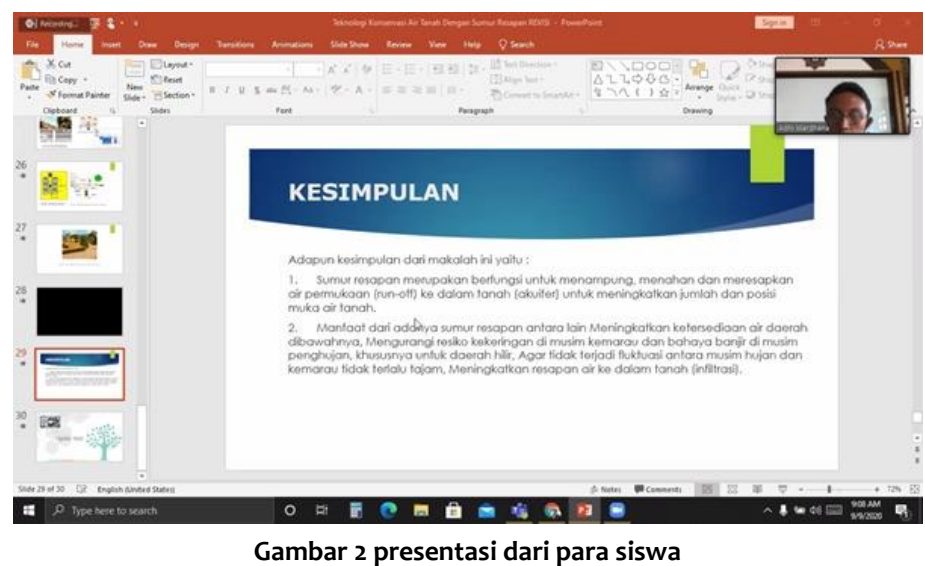

Kegiatan program pengabdian masyarakat dilanjutkan dengan sistem monitoring terhadap keberlanjutan penguasaan materi dan aplikasi teknologi pengolahan air bersih. Keberlanjutan program ditunjukkan dengan peningkatan pengetahuan, pemahaman dan 
penguasaan teknologi oleh guru sehingga kedepannya dapat melanjutkan pengembangan teknologi tersebut di lingkungannya.

\section{Hasil dan Pembahasan}

Air dikatakan bersih ketika memenuhi 3 aspek, yaitu aspek kimia, fisika dan biologi. Adapun salah satu standar air minum dapat dilihat pada PERMENKES nomor 492 tahun 2010 berikut merupakan Tabel 1 standar air dikatakan dapat diminum adalah sebagai berikut

\begin{tabular}{ll}
\multicolumn{2}{c}{ Tabel 1 Standar Air Minum } \\
\hline Syarat & Air Minum (Maksimal) \\
\hline TDS $(\mathrm{mg} / \mathrm{l})$ & 500 \\
Suhu $\left({ }^{\circ} \mathrm{C}\right)$ & \pm 3 \\
$\mathrm{pH}$ & $6,5-8,5$ \\
DHL (p mhos/cm) & 5 \\
Kekeruhan (Skala NTU) & Tidak Berbau \\
Bau & Jernih \\
Warna & 0 \\
Bakteri E.Coli (jumlah/100 ml sampel) & 0 \\
Total Bakteri Koliform (jumlah/100 ml & 0 \\
sampel) & \\
\hline
\end{tabular}

Salah satu metode sederhana pengolahan air bersih adalah menggunakan metode penyaringan. Metode ini menggunakan beberapa media yang tersusun dan dilalui oleh air yang akan dikelola. Beberapa media tersebut adalah ijuk, pasir halus, kerikil, batu, arang aktif dan terkadang ada yang menambahkan zeolite. ijuk, pasir, kerikil dan batu digunakan untuk menyaring partikel-partikel kecil dan besar. Batu zeolite digunakan untuk mengikat kationkation dalam air seperti $\mathrm{Ca}, \mathrm{Mg}, \mathrm{Fe}$ dan $\mathrm{Al}$ yang umumnya terdapat pada air tanah (Wiyono, Faturrahman, \& Syauqiah, 2017). Arang Aktif berfungsi untuk menyerap senyawa-senyawa yang tidak diinginkan (Dinora \& Purnomo, 2013).

Selain penyaringan, metode lain adalah menggunakan disinfektan. Disinfektan bertujuan untuk membunuh virus dan bakteri dalam air. Contoh penerapannya adalah menggunakan sinar UV. Kelebihan menggunakan sinar UV karena tidak berbahaya dan tidak beracun sertamampu menghancurkan zat pencemar organic, menghilangkan bau dan rasa pada air dan waktu kontaknya relatif singkat. Akan tetapi sistem UV ini memiliki ketergantungan terhadap jumlah energi yang diserap, sehingga jika energinya tidak tinggi maka material organisme genetik tidak dapat dihancurkan (Wiyono, Faturrahman, \& Syauqiah, 2017)

Badan Pengkajian dan Penerapan Teknologi (BPPT) telah menyiapkan kurang lebih 10 paket pengolahan air bersih, 2 diantaranya adalah menggunakan teknologi air tanah dengan sumur resapan dan pengolahan air sungai/gambut sederhana. Adapun manfaat dari teknologi sumur resapan ini adalah menambah jumlah air tanah dan mengurangi limpasan atau genangan air pada permukaan sehingga dapat mencegah banjir (Bunganaen, Sir, \& Penna, 2016) (Rizal, Iqbal, \& Abduh, 2017). Gambar 3 menunjukkan skema teknologi sumur resapan

Sedangkan untuk mengelola air sungai/gambut cocok digunakan untuk wilayah-wilayah yang memiliki sumber air gambut yang cukup besar seperti di Pulau Kalimantan dan Sumatera (Wardiha, Putri, \& Said, 2016). Selain itu menurut pengolahan air gambut yang sederhana cocok untuk kepentingan keluarga baik di daerah pedesaan maupun perkotaan yang kualitas air tanahnya buruk dan belum mendapatkan pelayanan air bersih karena teknologi yang sederhana ini mudah dari segi pembuatan dan cara pengolahannya serta biaya produksinya tidak mahal (Said \& Wahjono, 1999). Gambar 3 menunjukan skema pembuatan pengolahan air sungai/gambut. 


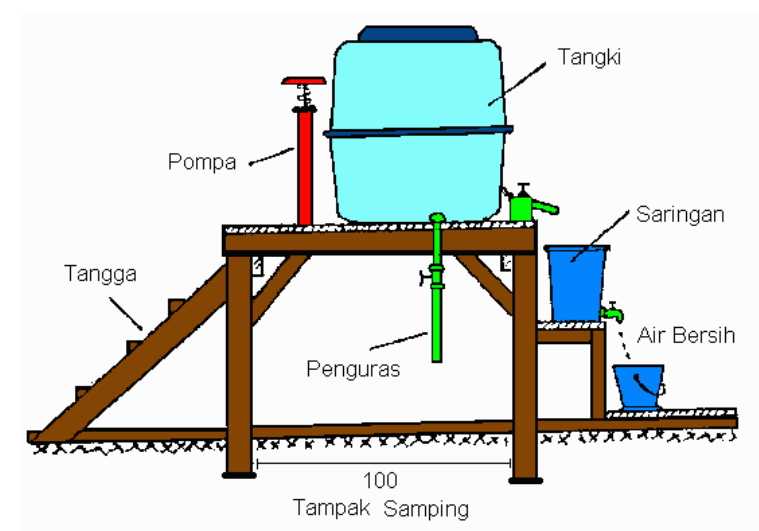

Gambar 3 skema teknologi pengolahan air bersih gambut

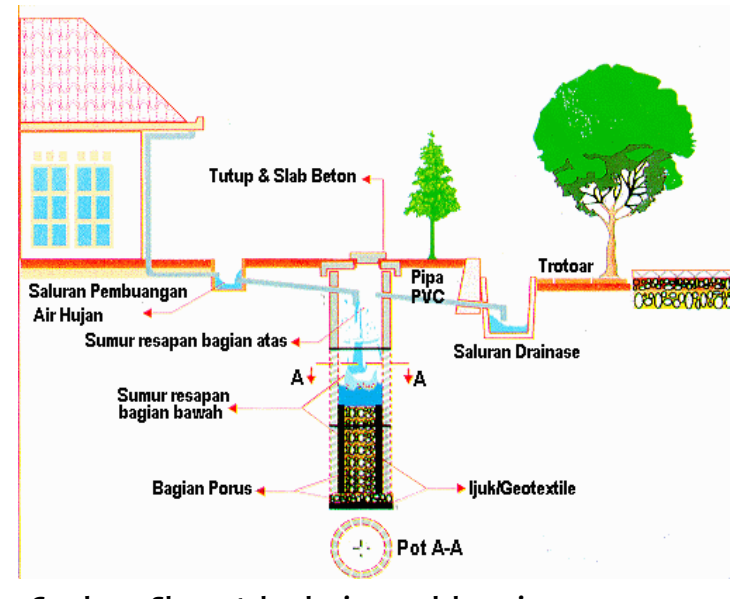

Gambar 4 Skema teknologi pengolahan air sumur resapan

Sebelum dan sesudah melakukan kegiatan pelatihan. Guru dan Siswa melakukan pretest dan posttest untuk mengetahui peningkatan kompetensi pada guru dan siswa SMA Luqman AlHakim. Hasil evaluasi tersebut ditampilkan pada Gambar 5 terkait nilai pretest dan posttest

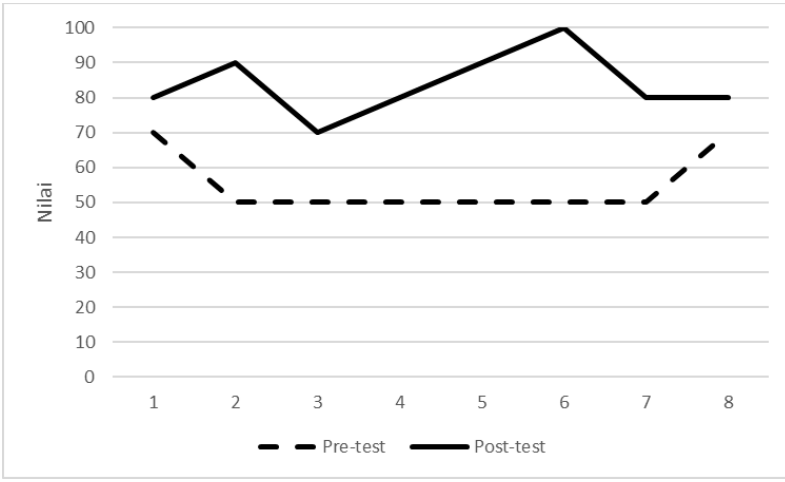

Gambar 5 Nilai Pre-test dan Post-test

Nilai rata-rata pretest dan posttest mengalami peningkatan yaitu dari nilai pretest sebesar 55 menjadi nilai posttest sebesar 83,75. Selain itu, Gambar 5 menjelaskan bahwa Guru dan Siswa yang mengikuti pelatihan pengolahan air bersih mengalami peningkatan nilai dari pretest menjadi nilai posttest. Hal ini menjelaskan bahwa Guru dan Siswa mengalami peningkatan pemahaman dan kompetensi tentang teknologi pengolahan air bersih. 
Selain itu 2 dari 8 peserta menyatakan sangat puas setelah mengikuti pelatihan pengolahan air bersih. Sedangkan sisanya sebanyak 6 orang menyatakan puas dengan pelatihan pengolahan air bersih.

\section{Simpulan}

Peserta pelatihan mengalami peningkatan pemahaman dan kompetensi mengenai teknologi pengolahan air bersih serta memahami aplikasi teknologi pengolahan air bersih untuk mendapatkan air yang bersih dan dapat diminum. Hal ini dibuktikan dengan meningkatnya nilai rata-rata pretest dan posttest. Selain itu, berdasarkan survei peserta pelatihan menyatakan bahwa pelatihan ini sangat berguna dan bermanfaat bagi bekal ilmu untuk kedepannya.

\section{Ucapan Terima Kasih}

Program pengadian masyarakat ini didanai oleh Departemen Teknik Material dan Metalurgi Fakultas Teknologi Industri Rekayasa Sistem (DTMM FTIRS) \& Direktorat Penelitian dan Pengabdian Kepada Masyarakat Institut Teknologi Sepuluh Nopember (DPPM ITS)

\section{Daftar Pustaka}

Bunganaen, W. dkk. (2016). PEMANFAATAN SUMUR RESAPAN UNTUK MEMINIMALISIR GENANGAN DISEKITAR JALAN CAK DOKO. Jurnal Teknik Sipil, 67 - 78.

Dinora, Q. G., \& Purnomo, A. (2013). Penurunan Kandungan Zat Kapur dalam Air Tanah dengan Menggunakan Media Zeolit Alam dan Karbon Aktif Menjadi Air Bersih. JURNAL TEKNIK POMITS, D78-D82.

Febriana, L., \& Ayuna, A. (2015). STUDI PENURUNAN KADAR BESI (FE) DAN MANGAN (MN) DALAM AIR TANAH MENGGUNAKAN SARINGAN KERAMIK. Jurnal Teknologi Universitas Muhammadiyah Jakarta, 35 - 44.

Indriatmoko, R. H., \& Wahjono, H. D. (1999). TEKNOLOGI KONSERVASI AIR TANAH DENGAN SUMUR RESAPAN. JAKARTA: BADAN PENGKAJIAN DAN PENERABAN TEKNOLOGI.

Rizal, S. dkk. (2017). KAJIAN PEMBUATAN SUMUR RESAPAN UNTUK PENANGGULANGAN GENANGAN AIR DI KAWASAN KAMPUS. Prosiding SENSEI 2017 (pp. 7-13). Jember: Jurnal unmuh jember.

Said, N. I., \& Wahjono, H. D. (1999). PENGOLAHAN AIR SUNGAI/GAMBUT SEDERHANA. JAKARTA: BADAN PENGKAJIAN DAN PENERAPAN TEKNOLOGI.

Wardiha, M. dkk. (2016). DESAIN ALAT PENGOLAHAN AIR GAMBUT SEDERHANA PADA AIR SUNGAI TAMBA, DESA BAHU PALAWA, KALIMANTAN TENGAH. Prosiding Seminar Pekan Inovasi Sains dan Teknologi 2016 (pp. 25 -33). Bandung: Pusat Penelitian dan Pengembangan Perumahan dan Permukiman.

Wiyono, N. dkk. (2017). SISTEM PENGOLAHAN AIR MINUM SEDERHANA (PORTABLE WATER TREATMENT). KONVERSI, 27 - 35.

Yudo, S., \& Said, N. I. (2019). Kondisi Kualitas Air Sungai Surabaya Studi Kasus: Peningkatan Kualitas Air Baku PDAM Surabaya. Jurnal Teknologi Lingkungan, 19-28. 